\title{
CATABOLISM AND INTERCONVERSION OF CORTISOL AND CORTISONE IN HUMAN SYNOVIAL TISSUE IN VITRO
}

\author{
BY \\ D. MURPHY AND H. F. WEST \\ Rheumatism Research Unit, Nether Edge Hospital, Sheffield
}

The object of this study has been to find out whether cortisol and cortisone are interconverted and catabolized in human rheumatoid synovial tissue and to identify the catabolites. No formal comparison of rheumatoid and non-rheumatoid synovial tissue has been made, but sufficient evidence has been obtained to justify such a study. That extra-hepatic tissues are able to metabolize cortisol in vitro has been demonstrated by very many authors, but the relevance of this to events in vivo has been in doubt as it has been generally assumed that cortisol is almost entirely metabolized in the liver. From indirect evidence Murphy and West (1964) deduced that this assumption was incorrect, and now Bailey and West (1969) have confirmed this and have shown that under normal conditions it is the extrahepatic tissues that are mainly responsible for the interconversion and catabolism of cortisol and cortisone. Hence the past studies in vitro and those of this paper are very relevant to physiological and pathological processes. It is possible that a localized tissue could have a subnormal effective concentration of cortisol that would, among other things, reduce the stability of lysosomes. Such a state of affairs might be advantageous in some circumstances and the reverse in others.

\section{Material and Methods}

\section{Synovial Tissue}

The entire synovial tissue removed at operation from a knee was used in the case of three patients with rheumatoid arthritis (RA).

RA (1) A man aged 44 with very active RA who was receiving a nigh level of adrenocortical stimulation with ACTH.

RA (2) A woman aged 33 who had no general rheumatoid activity. The tissue came from a knee that had a thickened synovial membrane and had been the site of recurrent effusions over many years.

RA (3) A man aged 44 who had moderately active RA and in whom the synovial membrane was chronically thickened.
$\mathrm{Db}$ (1) and $\mathrm{Db}$ (2) were women aged 73 with wellcontrolled diabetes who had gangrene of the toes. GrittiStokes' amputations were performed and the synovial tissue dissected from the lower part of the joint excluding the suprapatellar pouch.

The rheumatoid tissue included the suprapatellar pouch and contained much fat. It was histologically typical of RA. That from the diabetic subjects contained little fat, was much less in quantity, and was not studied histologically.

\section{Radioactive Steroids}

Cortisol-4-14 C ( ${ }^{14} \mathrm{C}$-cortisol), specific activity $156 \mu \mathrm{Ci}$./ mg., cortisone-1,2- $\mathrm{T}$ ( ${ }^{3} \mathrm{H}$-cortisone), specific activity $94 \mu \mathrm{Ci} . / \mu \mathrm{g}$., and cortisol-1,2-T, specific activity $60 \mu \mathrm{Ci} . / \mu \mathrm{g}$. were obtained from the Radiochemical Centre, Amersham and were re-purified before use in the Bush B5 chromatography system (Bush, 1961). The quantities used for each incubation from RA (2), RA (3), Db (1), and Db (2) were approximately $0.1 \mu \mathrm{g}$. ${ }^{3} \mathrm{H}$-cortisone $(10 \mu \mathrm{Ci}$.); $6 \mu$ g. ${ }^{14} \mathrm{C}$-cortisol $\left(1 \mu \mathrm{Ci}\right.$.). Only ${ }^{3} \mathrm{H}$-cortisol (0.075 $\mu \mathrm{g}$. $4 \cdot 5 \mu \mathrm{Ci}$.) was added to the incubates from RA (1).

\section{Incubation}

The excised tissue was immediately cut into small fragments and placed in $100 \mathrm{ml}$. Krebs-Henseleit medium. The medium, previously gassed with 95 per cent. oxygen and 5 per cent. $\mathrm{CO}_{2}$, was gassed again, the radioactive steroids were added, and incubation was carried out at $37^{\circ} \mathrm{C}$. for $2 \mathrm{hrs}$. At the end of this time the medium was poured off and $100 \mathrm{ml}$. physiological saline were added to the tissue which was then left over-night at $37^{\circ} \mathrm{C}$.

\section{Extraction}

One-tenth of the medium and of the saline (into which the tissue steroids had diffused) was made up to $50 \mathrm{ml}$. with water and extracted with $3 \times 1$ vol. freshly distilled ethyl acetate. The extracts were washed with $0 \cdot 1$ vol. N.Na ${ }_{2} \mathrm{CO}_{3}, 1 / 20$ th vol. saturated $\mathrm{NaCl}$ and $1 / 20$ th vol. 2 per cent. acetic acid. The tissue was shaken for $1 \mathrm{hr}$ at $37^{\circ} \mathrm{C}$. with $100 \mathrm{ml}$. ethanol. The ethanol was then replaced with a second $100 \mathrm{ml}$. and reshaken. The combined ethanol extracts were evaporated to dryness and transferred to a separating funnel with $100 \mathrm{ml}$. freshly distilled ethyl acetate and $100 \mathrm{ml}$. water. The 
ethyl acetate extract was further purified as for the medium and saline above. The water in each extract was frozen out and the subsequently evaporated extracts partitioned between $1 \mathrm{ml}$. petroleum ether $\left(100-120^{\circ}\right)$ and $4 \mathrm{ml}$. 70 per cent. methanol. The petroleum ether layer was removed and the aqueous methanol extract evaporated to dryness.

\section{Chromatography}

Extracts were run in duplicate in the Bush B5 chromatography system (Bush, 1961) at $28^{\circ}$ in a constant temp. room until the solvent front had progressed $38-39 \mathrm{~cm}$. One of each pair was cut into 38 to $401-\mathrm{cm}$. strips for elution and radioactivity measurement. On the basis of these measurements four regions were cut from the duplicate chromatograms for further analysis of the more polar metabolites (mainly 20-dihydrocortisols), the less polar metabolites (mainly 20-dihydrocortisones), cortisol, and cortisone (see Fig. 1). An aliquot of each eluate was acetylated and run in the Bush 3b system (Bush, 1961). In the case of RA (1), another aliquot of each eluate was oxidized with sodium bismuthate and run in the Smith VI system (Smith, Foell, De Maio, and Halwer, 1959), and aliquots of the most polar region from RA (1), RA (3) and $\mathrm{Db}$ (2) were run in the Smith II system (Smith and others, 1959). For further identification of cortisol, cortisone, $20 \alpha$-dihydrocortisol, $20 \beta$-dihydrocortisol, 20adihydrocortisone, and 20 $\beta$-dihydrocortisone, larger aliquots of the extracts were chromatographed and the named steroids isolated as their acetates. The combined peaks of $20 \alpha$ and $20 \beta$-dihydrocortisone were eluted and separated by thin layer chromatography using 5 per cent. ethanol in ether. To each isolate was added $5 \mathrm{mg}$. of the relevant standard steroid acetate and the specific activity measured. The steroids were then crystallized from acetone/hexane or acetone/methanol/hexane four times. Each time the specific activities of the mother liquor and the crystals were measured.

\section{Radioactivity Measurements}

A "Tricarb" Model 3003 liquid scintillation spectrometer was used. To specimens in $1 \mathrm{ml}$. ethanol, $10 \mathrm{ml}$. Butyl-PBD was added (Ciba 6g./1). For chromatogram eluates and clean extracts the efficiencies were in the tritium channel for tritium $16 \cdot 5$ per cent. and for ${ }^{14} \mathrm{C}$ 4 per cent.; in the ${ }^{14} \mathrm{C}$ channel, ${ }^{14} \mathrm{C} 58$ per cent.

\section{Results}

More than 90 per cent. of the radioactivity added was recovered in the ethyl acetate extracts, thus showing that if conjugates were present at all the amount was very small.

\section{Controls}

In RA (1) and RA (2) the tissues were divided into two and placed in separate flasks with incubation media. One, the control, was immersed in a boiling water bath for $10 \mathrm{~min}$. Both were subsequently processed in the same way. The standard radioactive steroids used for RA (1) and RA (2) were also extracted and chromatographed as for the incubates. In both cases some impurities were found that were the same in the standards as in the $\frac{0}{\circ}$. heated cultures. Fig. 1 shows the saline diffusate: extract and control saline diffusate extract of RA (2) on B5 chromatograms. It will be seen that thereo was a little radioactivity of highly polar nature in theo control. When the most polar region of the $B 5 \frac{\overline{\bar{N}}}{\overline{5}}$ chromatograms were eluted and acetylated and run $\mathbb{\complement}$ in the Smith VI system, some unidentified radio- 0 activity stayed near the origin-this may have been ${ }_{-}^{\text {s }}$ the contaminating material. Fig. 1 also shows that? there was some radioactivity near the solvent front $\vec{\overrightarrow{ }}$ where 11-desoxy-17-oxosteroids would run. Thiso area of the incubate chromatograms was not further studied.

\section{Identification of the Steroids}

Fraction 1 (Fig. 1).-In each case this fraction was eluted from the duplicate B5 chromatogram, acety-? lated, and run in the Smith VI system. Fig. 2 shows a representative Smith VI chromatogram (from Db2). The peak at the origin, the identity of which was unknown, was always most prominent in the medium? extract. The 2 nd and 3rd peaks have the Rfs of 20 $\beta$-dihydrocortisol and 20a-dihydrocortisol acetates respectively. The diffuse double peak near 迎e solvent front corresponded in $\mathrm{Rf}$ to the diacetates of the cortols and cortolones. In RA (1), fractiono I run in the Smith II system gave a small peak withs the $\mathrm{Rf}$ of $6 \beta$-hydroxycortisol, but in RA (3) and $\mathrm{Db}(2)$ there was no such peak. In the Smith Vo chromatograms of the acetates, $6 \beta$-hydroxycortiso diacetate, if present, would have run with $20 \beta \overrightarrow{\overrightarrow{0}}$ dihydrocortisol diacetate. $20 \alpha$ and $20 \beta$-dihydro cortisol were further identified in the tissue and saline extracts of RA (1) and RA (2) by crystallization of their diacetates to constant specific activity with standards. Table I gives the findings in RA (2), which confirmed that the eluted steroids contained little contaminating material.

TABLE I

CRYSTALLIZATION TO CONSTANT SPECIFIC ACTIVITY ำ OF 200 and $20 \beta$-DIHYDROCORTISOL ACETATES ELUTED FROM CHROMATOGRAMS (m $\mu \mathrm{Ci}$./mg.)

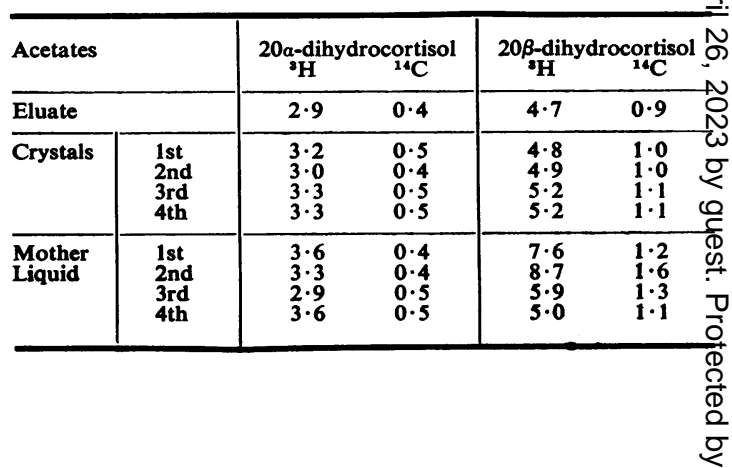



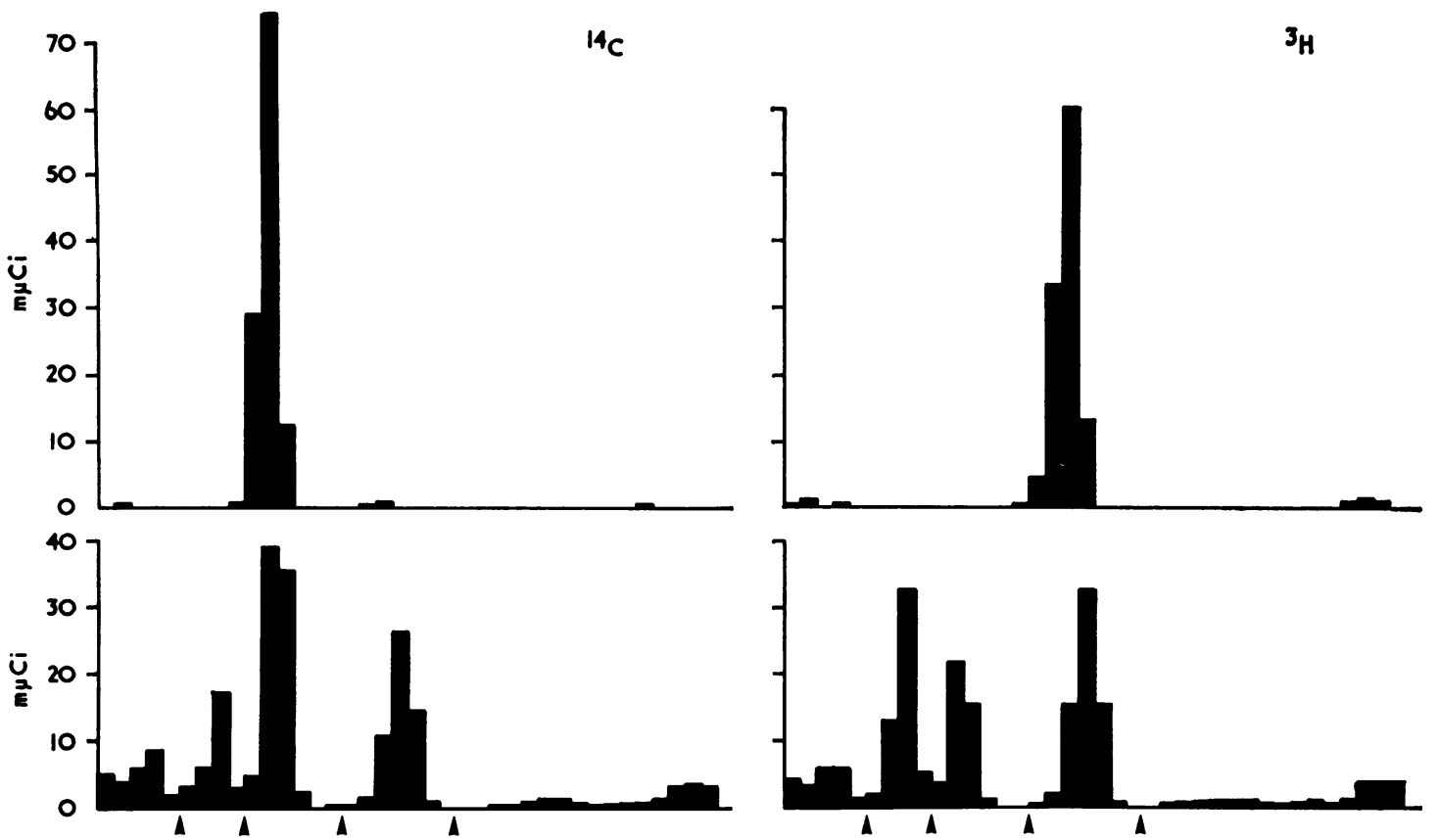

Fig. 1.-Distribution of ${ }^{14} \mathrm{C}$ derived from cortisol and ${ }^{2} \mathrm{H}$ derived from cortisone in the B5 paper chromatograms $(1 \mathrm{~cm}$. strips) of the extracts of the saline diffusates from the synovial tissue incubates of Subject RA (2). Upper chromatograms from the control inactivated tissue incubate. Arrows denote positions at which cuts were

made for the four fractions further analysed.

Starting from the left the fractions were:

1. the most polar containing the 20-dihydrocortisols;

2. less polar, containing the 20-dihydrocortisone;

3. cortisol;

4. cortisone.

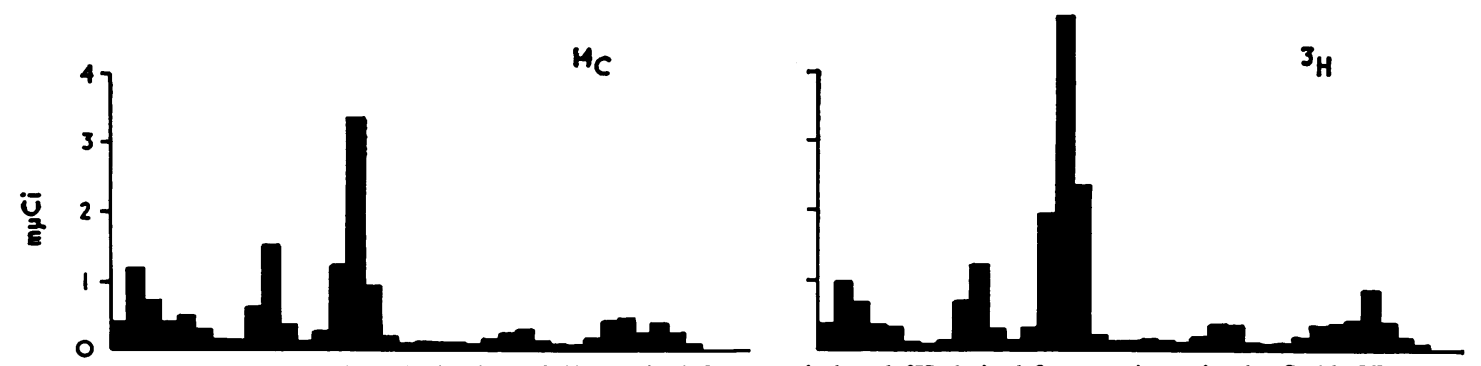

Fig. 2.- Chromatograms, showing distribution of ${ }^{11} \mathrm{C}$ derived from cortisol and ${ }^{2} \mathrm{H}$ derived from cortisone in the Smith Vl acetate chromatogram from Fraction 1 of the B5 chromatogram of the saline diffusate extract from the tissue incubate of subject Db (2). The major adjacent peaks have the $R$ fs of $20 \beta$ and $20 \alpha$-dihydrocortisol acetates. The double peaks near the solvent front (right side) are in the position of standard cortol and cortolone diacetate.

Fraction 2 (Fig. 1).-In each case this fraction of the B5 chromatogram was eluted, acetylated, and run in the Smith VI system. Fig. 3 (overleaf) shows the chromatogram from the saline diffusate extract of RA (3). The large peak corresponds to $20 \beta$ and 20a-dihydrocortisone diacetates. For the other subjects this peak was grossly asymmetrical with the most polar " $20 \beta$ " acetate in least amount. The small diffuse double peak corresponds in $\mathbf{R f}$ to the diacetates of THF (tetrahydrocortisol), alloTHF, and THE (tetrahydrocortisone). In most instances the least polar THE component was prominent in the ${ }^{3} \mathrm{H}$ chromatograms, i.e. derived from ${ }^{3} \mathrm{H}$-cortisone. In RA (1) and RA (2) the 20a and $20 \beta$-dihydrocortisones were isolated as diacetates by thin layer chromatography and crystallized repeatedly with added standard to constant specific activity. No major change in specific activity occurred so their identity was considered to be certain.

Fraction 3.- In each case this cortisol region was eluted from the B5 chromatograms, acetylated, and re-run in the Smith VI system to give a single peak 

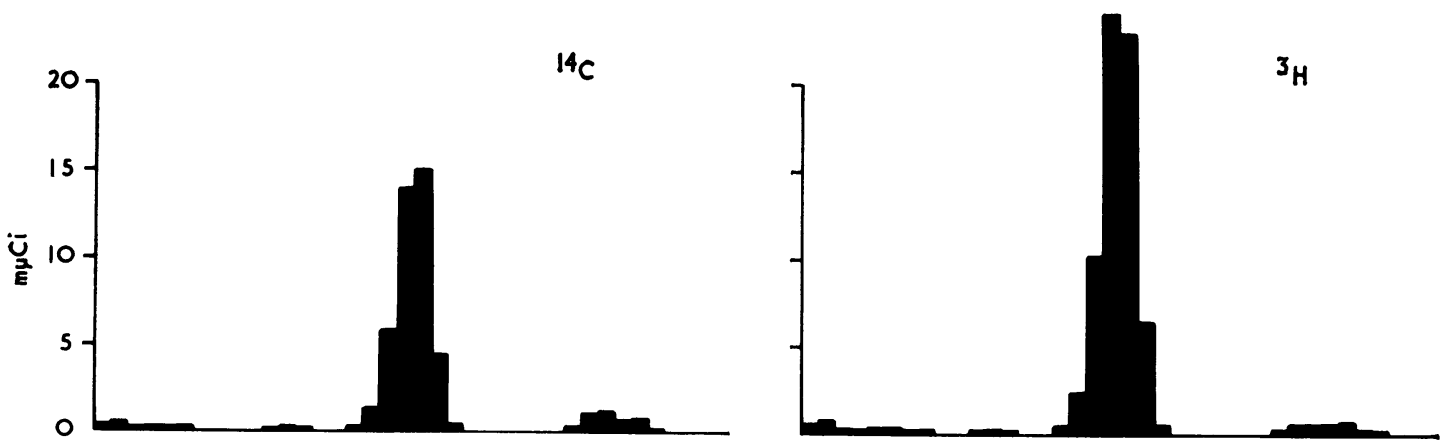

Fig. 3.-Chromatograms, as in Fig. 2, but showing Fraction 2 from subject RA (3). The large peak ran with 20 $\beta$ and 20 $\alpha$-dihydrocortisone acetate. The small diffuse peak towards the solvent front corresponded to combined standards of THF and THE diacetates.

with the $\mathrm{Rf}$ of standard cortisol acetate. In RA (1) and RA (2) the B5 cortisol region was crystallized with standard to constant specific activity (4 crystallizations) without significant change in the specific activities.

Fraction 4.-This fraction was treated the same as Fraction 3 and was shown similarly to be pure cortisone. In RA (1), the region of the B5 chromatogram less polar than cortisone was eluted and the eluate re-run in the Bush $3 \mathrm{~b}$ chromatography system. Two peaks were seen that had the $R f s$ of standard $11 \beta$-hydroxyandrostenedione and 11-oxo-androstenedione - the 17-oxosteroids derived from cortisol and cortisone respectively.

\section{Qualitative and Quantitative Aspects of Cortisol and Cortisone Metabolism}

The upper part of Table II shows the percentage of ${ }^{14} \mathrm{C}$ derived from cortisol and ${ }^{3} \mathrm{H}$ derived from cortisone that ended up in cortisol, cortisone, and a group of catabolites. The percentages were of the totals of the B5 chromatograms of the tissue extracts $\underset{v}{ }$ $(\mathrm{T})$, the saline diffusate extracts (S), and the medium 은 extracts $(\mathrm{M})$; e.g. if Fraction $1\left({ }^{14} \mathrm{C}\right)$ was 10 per cent. of the B5 chromatogram, and 20a-dihydrocortisol $\left({ }^{14} \mathrm{C}\right)$ was 5 per cent. of the Fraction 1 acetate chromatogram, then $20 a$-dihydrocrotisol $\left({ }^{14} \mathrm{C}\right)$ contributed 0.5 per cent. to the percentage of ${ }^{14} \mathrm{C}$ catabolites.

The catabolites included in the total figure given were $20 \alpha$ and $20 \beta$-dihydrocortisol, $20 \alpha$ with $20 \beta$ dihydrocortisone, and the radioactivity in the $10 \mathrm{~cm}$ strips encompassing the cortols and cortolones of Fraction 1 and the THFs and THE of Fraction 2 (cortisol and cortisone were not included). In considering the figures it may be borne in mind that in RA (2), RA (3), Db (1), and Db (2) approximately $6 \mu \mathrm{g}$. of cortisol was in the $100 \mathrm{ml}$. of culture medium used and only approximately $0 \cdot 1 \mu \mathrm{g}$. of cortisone.

TABLE II

PERCENTAGE DISTRIBUTION OF ${ }^{14} \mathrm{C}$ DERIVED FROM CORTISOL AND ${ }^{3} \mathrm{H}$ DERIVED FROM CORTISONE IN THE CHROMATOGRAM PEAKS CORRESPONDING TO CORTISOL, CORTISONE, AND A GROUP (SEE TEXT) OF THEIR METABOLITES

\begin{tabular}{|c|c|c|c|c|c|c|c|c|c|c|c|c|c|c|c|c|}
\hline \multirow{2}{*}{ Isotope } & \multirow{2}{*}{ Steroid } & \multicolumn{3}{|c|}{ RA (1) } & \multicolumn{3}{|c|}{ RA (2) } & \multicolumn{3}{|c|}{ RA (3) } & \multicolumn{3}{|c|}{$\mathrm{Db}(1)$} & \multicolumn{3}{|c|}{$\mathrm{Db}(2)$} \\
\hline & & $T$ & $\mathbf{S}$ & $\mathbf{M}$ & $T$ & $\mathbf{S}$ & $\mathbf{M}$ & $\mathrm{T}$ & $\mathbf{S}$ & $\mathbf{M}$ & $\mathbf{T}$ & $\mathbf{S}$ & $\mathbf{M}$ & $\mathbf{T}$ & $\mathbf{S}$ & $\mathbf{M}$ \\
\hline Percentage of ${ }^{14} \mathrm{C}$ & $\begin{array}{l}\text { Cortisol } \\
\text { Cortisone }\end{array}$ & $\begin{array}{l}44 \\
25\end{array}$ & $\begin{array}{l}39 \\
27\end{array}$ & $\begin{array}{l}68 \\
13\end{array}$ & $\begin{array}{l}33 \\
25\end{array}$ & $\begin{array}{l}32 \\
20\end{array}$ & $\begin{array}{l}82 \\
10\end{array}$ & $\begin{array}{l}42 \\
23\end{array}$ & $\begin{array}{l}39 \\
20\end{array}$ & $\begin{array}{l}68 \\
12\end{array}$ & $\begin{array}{l}52 \\
13\end{array}$ & $\begin{array}{l}61 \\
14\end{array}$ & $\begin{array}{l}80 \\
11\end{array}$ & $\begin{array}{l}41 \\
11\end{array}$ & $\begin{array}{l}51 \\
23\end{array}$ & $\begin{array}{r}87 \\
7\end{array}$ \\
\hline Percentage of ${ }^{3} \mathrm{H}$ & $\begin{array}{l}\text { Cortisone } \\
\text { Cortisol }\end{array}$ & & & & $\begin{array}{l}29 \\
17\end{array}$ & $\begin{array}{l}27 \\
17\end{array}$ & $\begin{array}{l}67 \\
17\end{array}$ & $\begin{array}{l}23 \\
25\end{array}$ & $\begin{array}{l}19 \\
22\end{array}$ & $\begin{array}{l}56 \\
16\end{array}$ & $\begin{array}{l}14 \\
46\end{array}$ & $\begin{array}{l}15 \\
53\end{array}$ & $\begin{array}{l}65 \\
22\end{array}$ & 31 & $\begin{array}{l}22 \\
40\end{array}$ & $\begin{array}{l}67 \\
20\end{array}$ \\
\hline $\begin{array}{l}\text { Percentage of }{ }^{14} \mathrm{C} \\
\text { Percentage of }{ }^{8} \mathrm{H}\end{array}$ & Catabolites & 16 & 16 & - & $\begin{array}{l}14 \\
20\end{array}$ & $\begin{array}{l}14 \\
22\end{array}$ & $\begin{array}{l}3 \\
7\end{array}$ & $\begin{array}{l}27 \\
44\end{array}$ & $\begin{array}{l}30 \\
47\end{array}$ & $\begin{array}{r}7 \\
15\end{array}$ & $\begin{array}{l}11 \\
14\end{array}$ & $\begin{array}{l}12 \\
20\end{array}$ & $\begin{array}{l}2 \\
2\end{array}$ & 21 & $\begin{array}{l}27 \\
28\end{array}$ & $\begin{array}{l}2 \\
6\end{array}$ \\
\hline $\begin{array}{l}\text { Percentage of }{ }^{14} \mathrm{C} \\
\text { Percentage of }{ }^{8} \mathrm{H}\end{array}$ & Catabolites & & & & & $\begin{array}{r}S+ \\
11 \\
6\end{array}$ & & & $\begin{array}{r}\mathrm{S} \\
29 \\
19\end{array}$ & & & $\begin{array}{l}S \\
6 \\
4\end{array}$ & & & $\begin{array}{l}S+ \\
0 \\
7\end{array}$ & \\
\hline \multicolumn{5}{|c|}{ Ratio $\frac{\text { Cortisol derived from Cortisone }}{\text { Cortisone derived from Cortisol }}$} & \multicolumn{3}{|c|}{$1 \cdot 3$} & \multicolumn{3}{|c|}{$1 \cdot 2$} & \multicolumn{3}{|c|}{$2 \cdot 4$} & \multicolumn{3}{|c|}{$2 \cdot 5$} \\
\hline \multicolumn{5}{|c|}{ Ratio Tissue and Saline Only } & \multicolumn{3}{|c|}{$0 \cdot 8$} & \multicolumn{3}{|c|}{$1 \cdot 0$} & \multicolumn{3}{|c|}{$3 \cdot 7$} & \multicolumn{3}{|c|}{$3 \cdot 0$} \\
\hline
\end{tabular}


The subjects from whom these tissues were obtained were not receiving corticosteroids, but it is likely that their plasma cortisol concentrations were raised somewhat by stress at the time when the tissue was excised. One can guess what the concentrations of cortisol and cortisone would have been in their tissues but only between fairly wide limits. Taking the normal non-protein-bound diffusible concentration of plasma cortisol as $0 \cdot 5-1 \cdot 0 \mu \mathrm{g} . / 100 \mathrm{ml}$. (total $10 \mu \mathrm{g} . / 100 \mathrm{ml} ., 5$ to 10 per cent. free), one may guess the diffusible concentration in the metabolizing tissue cells as $1-4 \mu \mathrm{g} . / 100 \mathrm{~g}$. with a possible total concentration of $3-12 \mu \mathrm{g}$. $/ 100 \mathrm{~g}$. The $6 \mu \mathrm{g}$. $/ 100 \mathrm{ml}$. of diffusible cortisol in the medium would thus be likely to provide substrate for metabolism and particularly so as the tissue concentration fell. In the case of cortisone the concentration gradient would have been markedly reversed as the diffusible concentration of plasma cortisone is not much less than that of cortisol. In spite of the loss of cortisone to the medium it is seen that at the end of the incubation much newly-formed cortisone was present in the tissue, e.g. in the case of RA (3) there was at least half as much newly-formed cortisone remaining as there was of unaltered cortisol-which latter might have been at a higher concentration than initially if there was a substrate-tissue gradient. Similarly it may be seen that there was at least as much newlyformed cortisol remaining as there was of unaltered cortisone. The quantities referred to are, of course, of steroid and not of radioactivity.

The lower half of Table II shows the percentage of the total cortisol and cortisone present in the tissue and medium that was converted to the named catabolites-assuming that the ${ }^{14} \mathrm{C}$ and ${ }^{3} \mathrm{H}$ labels diffused freely through the tissue. It also gives the interesting figures for the ratio of cortisol present derived from cortisone/cortisone present derived from cortisol.
Table III gives detail of the percentage of ${ }^{14} \mathrm{C}$ and ${ }^{3} \mathrm{H}$ that ended up as the $20 \alpha$ and $20 \beta$ stereoisomers of 20-dihydrocortisol and 20-dihydrocortisone together with the $\alpha / \beta$ ratios-in respect of the tissue and saline extracts. Of interest is the finding that relatively more of the $20 a$ stereoisomer was formed when cortisone was the original substrate-as if the 11-oxo function was less favourable for the fit of the $20 \beta$-steroid-dehydrogenase. It may be noted that the $20 a / 20 \beta$ ratio also varied directly with the percentage of cortisone converted to cortisol (Table I) suggesting that some $20 a$-dihydrocortisone was reduced to $20 a$-dihydrocortisol.

\section{Discussion}

Dougherty and his co-workers (see Berliner, 1961) have shown, in a series of studies, that connective tissue cells are able to metabolize cortisol and cortisone, in cultures in vitro, in a qualitatively similar way to that reported above for human knee synovial tissue. The generally accepted assumption that cortisol and cortisone are interconverted and catabolized almost entirely in the liver has made all studies in vitro of the metabolism of these steroids in extrahepatic tissues of rather academic interest. Now that it is known that the assumption is unjustified and that it is the extrahepatic tissues that normally play the major role in their interconversion and catabolism (Bailey and West, 1969), the results in vitro have become of great interest. A number of attempts have been made to detect cortisol metabolism in rheumatoid knee joints by injecting cortisol and later withdrawing synovial fluid for analysis: e.g. Wilson, Fairbanks, Scialabba, McEwen and Ziff (1956), Peterson, Black, and Bunim (1959), Winter, Sandberg, Saroff, and Slaunwhite (1967). Only Wilson and others (1956) had some success and this may have been due to the fact that they

TABLE III

PERCENTAGE OF RADIOACTIVITY PRESENT AS THE 20-DIHYDRO ISOMERS OF CORTISOL AND CORTISONE AND THE 20 $\alpha / 20 \beta$-DIHYDRO RATIOS B5 CHROMATOGRAMS OF TISSUE AND SALINE DIFFUSATE EXTRACTS

\begin{tabular}{|c|c|c|c|c|c|c|c|c|}
\hline \multirow{4}{*}{ Subject } & \multicolumn{4}{|c|}{$20 \alpha$ and $20 \beta$-dihydrocortisol } & \multicolumn{4}{|c|}{$20 a$ and $20 \beta$-dihydrocortisone } \\
\hline & \multicolumn{2}{|c|}{$\alpha / \beta$ Ratios } & \multicolumn{2}{|c|}{ Percentage of B5 } & \multicolumn{2}{|c|}{$a / \beta$ Ratios } & \multicolumn{2}{|c|}{ Percentage of B5 } \\
\hline & ${ }^{14} \mathrm{C}$ & ${ }^{\mathbf{2}} \mathbf{H}$ & ${ }^{14} \mathrm{C}$ & ${ }^{3} \mathbf{H}$ & ${ }^{14} \mathrm{C}$ & ${ }^{8} \mathrm{H}$ & ${ }^{14} \mathrm{C}$ & ${ }^{8} \mathrm{H}$ \\
\hline & Tiss.-Sal. & Tiss.-Sal. & Tiss.-Sal. & Tiss.-Sal. & Tiss.-Sal. & Tiss.-Sal. & Tiss.-Sal. & Tiss.-Sal. \\
\hline $\begin{array}{l}\mathbf{R A ~ ( 1 ) ~} \\
\mathbf{R A}(2) \\
\mathbf{R A ~ ( 3 ) ~} \\
\mathbf{D b}(1) \\
\text { Db (2) }\end{array}$ & $\begin{array}{l}0 \cdot 2-0 \cdot 2 \\
0 \cdot 6-0 \cdot 6 \\
1 \cdot 4-1 \cdot 5 \\
2 \cdot 3-4 \cdot 1 \\
2 \cdot 0-2 \cdot 7\end{array}$ & $\begin{array}{l}0 \cdot 9-1 \cdot 1 \\
2 \cdot 3-2 \cdot 5 \\
4 \cdot 8-6 \cdot 8 \\
2 \cdot 7-3 \cdot 9\end{array}$ & $\begin{array}{l}6 \cdot 4-5 \cdot 5 \\
3 \cdot 5-2 \cdot 5 \\
5 \cdot 3-5 \cdot 6 \\
4 \cdot 7-5 \cdot 0 \\
7 \cdot 5-4 \cdot 9\end{array}$ & $\begin{array}{r}2 \cdot 4-1 \cdot 6 \\
4 \cdot 9-5 \cdot 3 \\
6 \cdot 1-6 \cdot 9 \\
11 \cdot 0-6 \cdot 6\end{array}$ & $\begin{array}{c}1 \cdot 1-2 \cdot 2 \\
2 \cdot 9-3 \cdot 7^{1} \\
- \\
-\end{array}$ & $\begin{array}{c}3 \cdot 3-4 \cdot 0^{1} \\
-\end{array}$ & $\begin{array}{c}6 \cdot 3-7 \cdot 3 \\
8 \cdot 7-9 \cdot 8 \\
18 \cdot 0-10 \cdot 0 \\
3 \cdot 6-4 \cdot 9 \\
11 \cdot 0-10 \cdot 0\end{array}$ & $\begin{array}{r}15 \cdot 0-18 \cdot 0 \\
34 \cdot 0-37 \cdot 0 \\
6 \cdot 0-10 \cdot 0 \\
17 \cdot 0-17 \cdot 0\end{array}$ \\
\hline
\end{tabular}

${ }^{1}$ Combined 20-dihydrocortisone isolated from medium, tissue, and saline and purified to constant specific activity with standards gave a ${ }^{14} \mathrm{Ca} / \beta$ ratio of $2 \cdot 4$ and ${ }^{3} \mathrm{H} \alpha / \beta$ ratio of $3 \cdot 2$ 
washed out the synovial cavity. One imagines that any metabolites formed in the cells of the synovial tissue are rapidly carried away by the blood stream. Attempts have been made to detect a difference in the pattern of corticosteroid metabolites as between ultrafiltered plasma and synovial fluid (Bailey, Greaves, Murphy, and West, 1966) but they were unsuccessful. The only report of the metabolism of cortisol in rheumatoid synovial tissue in vitro was that of Murphy and West (1968), who found extensive metabolism.

In this paper the ability of human synovial tissue to interconvert and catabolize cortisol and cortisone in significant quantity has been demoustrated. The significance lies in the fact that a person of average size catabolizes cortisol at a rate of approximately $2.5 \mu \mathrm{g}$. $/ 100 \mathrm{~g}$. soft tissue $/ 2 \mathrm{hrs}$, and that the tissue incubates metabolized cortisol at a similar rate in what must have been unfavourable circumstances. In addition to cortisol and cortisone, four of their metabolites were identified under rigorous conditions and the presence of at least six other named metabolites was detected with reasonable certainty. Of particular interest to rheumatologists was the finding that the interconversion of cortisol and cortisone in two rheumatoid tissues was very different from that in two diabetic "controls"- a difference for which there was no obvious explanation other than that the cells of the rheumatoid tissue were by comparison deficient in their ability to convert cortisone to cortisol. (Normally both diffuse into the cells from the plasma.) It would seem unlikely that the quantity of tissue incubated would affect the pattern of metabolites in the conditions of the study or that the presence of fat would affect the cortisol/cortisone equilibrium - though this latter needs further study. The co-factors required for the interconversion of cortisol and cortisone are NAD and NADP, the latter being the more active (Rosenfeld, Fukushima, and Gallagher, 1967). Hsia and Hao (1967) have shown that the conversion of cortisone to cortisol by skin in vitro is enhanced three to four times by the addition of the reduced form of NADP $\left(\mathrm{NADPH}_{2}\right)$. One might postulate that in rheumatoid tissue there is a deficiency of $\mathrm{NADPH}_{2}$, but in view of the complexity of the molecular events involved this is not justified.

If it is confirmed that cortisol and cortisone are abnormally interconverted and metabolized in rheumatoid synovial tissue, it will be of interest to discover which type of cell is responsible and whether the abnormality is primary and/or secondary. If secondary it would be expected to enhance inflammation and if primary to lower the cell's threshold to disruption by noxious agents. In some patients with rheumatoid arthritis there are symptoms that are sensitive to very small doses of prednisolone. It may well be that these particular symptoms (e.g. morning stiffness) are provoked or aggravated by a subnormal tissue cell concentration of cortisol. Another clinical observation not yet understood is the rapid loss of effectiveness of cortisone and the less rapid loss of effectiveness of prednisolone during the treatment of severe rheumatoid arthritis. Grosser, Sweat, Berliner, and Dougherty (1962) have found that strains of fibroblasts vary in their ability to destroy cortisol. It is possible that, in the chronic inflammatory tissue of rheumatoid arthritis, fibroblasts or lymphocytes or both could adapt to raised concentrations of cortisol and prednisolone through the induction of $11 \beta$-hydroxysteroid-dehydrogenase and other cortisol inactivating enzymes.

\section{Summary}

The catabolism and interconversion of radioactive cortisol and cortisone in synovial tissue in vitro has been demonstrated. Specimens were obtained from three rheumatoid knee joints and from the knee joints of two subjects with well controlled diabetes who were having Gritti-Stokes's amputations for gangrene of the toes. Cortisol, cortisone, 20a-dihydrocortisol, 20 $\beta$-dihydrocortisol, 20a-dihydrocortisone, and $20 \beta$-dihydrocortisone were identified by recrystallization with standards to constant specific activity. From paper chromatographic findings, ring $\mathrm{A}$ reduction and side-chain cleavage also occurred. Of particular interest was the finding that the rheumatoid tissues converted more cortisol to cortisone and less cortisone to cortisol. This could mean that the effective concentration of cortisol was subnormal in the synovia of rheumatoid knees.

Thanks are due to Mrs. Norma Hobson, of the Sheffield Regional Medical Physics Dept. (Dr. H. Miller), for operating the liquid scintillation spectrometer, to the Medical Research Council for the major financial support, and to the Sheffield Regional Hospital Board for additional support.

\section{ADDENDUM}

Since this manuscript was submitted for publication (February, 1969), the metabolism of ${ }^{14} \mathrm{C}$ cortisol and ${ }^{3} \mathrm{H}$-cortisone has been studied in the synovial membrane from a normal knee of an elderly arteriosclerotic subject by Miss M. S. Greaves- 
using the same techniques as described above. The findings were essentially similar to those for the mildly diabetic controls. In this study it was found that the fat adjacent to the synovial membrane was much less active in metabolizing cortisol-on a weight basis. This raises the possibility that the differences between the rheumatoid and the control findings may be greater than those shown above as the rheumatoid synovia had more attached fat than the control synovia.

\section{REFERENCES}

Bailey, E., Greaves, M. S., Murphy, D., and West, H. F. (1966). Ann. rheum. Dis., 25, 516 (Corticosteroid metabolism and rheumatoid arthritis). and West. H. F. (1969). Acta endocr., 62, 339 (The secretion, interconversion and catabolism of cortisol, cortisone and some of their metabolites in man).

Berliner, D. L. (1961). In "Inflammation and Diseases of Connective Tissue," ed. L. C. Mills and J. H. Moyer, p. 431. Saunders, Philadelphia.

Bush, I. E. (1961). "The Chromatography of Steroids." Pergamon Press, Oxford.

Grosser, B. I., Sweat, M. L., Berliner, D. L., and Dougherty, T. F. (1962). Arch. Biochem. Biophys., 96, 259 (Comparison of cortisol metabolism by two variants of cultured fibroblasts).

Hsia, S. L., and Hao, Y.-L. (1967). Steroids, 10, 489 (Transformation of cortisone to cortisol in human skin).

Murphy, D., and West, H. F. (1964). Lancet, 1, 912 (Hydrocortisone metabolism).

- (1968). J. Endocr., 41, xxvii (The metabolism of $\left(1,2-{ }^{3} \mathrm{H}\right)$ cortisol in rheumatoid synovial tissue).

Peterson, R. E., Black, R. L., and Bunim, J. J. (1959). Arthr. and Rheum., 2, 433 (Disposition of intra-articularly injected cortisone and hydrocortisone).

Rosenfeld, R. S., Fukushima, D. K., and Gallagher, T. F. (1967). In "The Adrenal Cortex," ed. A. B. Eisenstein, p. 103. Little, Brown, Boston.

Smith, L. L., Foell, T., De Maio, R., and Halwer, M. (1959). J. Amer. pharm. Ass. (Scient. ed.), 48, 528 (Partition chromatography of triamcinolone and related steroids).

Wilson, H., Fairbanks, R., Scialabba, D., McEwen, C., and Ziff, M. (1956). J. clin. Endocr., 16, 86 (Metabolites of hydrocortisone and cortisone in synovial fluid in rheumatoid arthritis).

Winter, J. A., Sandberg, A. A., Saroff, J., and Slaunwhite, W. R. (1967). Arthr. and Rheum., 10, 352 (Disposition and metabolism of intra-articularly injected 4-C ${ }^{14}$-cortisol in rheumatoid arthritis).

Le catabolisme et l'interconversión in vitro du cortisol et de la cortisone du tissu synovail humain

\section{RÉSUMÉ}

Le catabolisme et l'nterconversion du cortisol et de la cortisone radioactifs dans le tissu synovial ont été démontrés in vitro. Les spécimens ont été obtenus de l'articulation du genou de trois malades atteints de polyarthrite rhumatoïde et de deux sujets atteints de diabète bien contrôlé et qui avaient subi l'amputation de Gritti-Stokes pour la gangrène des orfeils. Du cortisol de la cortisone, du $20 a$-dihydrocortisol, du $20 \beta$-dihydrocortisol, de la $20 a$-dihydrocortisone, et de la $20 \beta$-dihydrocortisone ont été identifiés par recristallisation avec les normes montrant une activité spécifique constante. D'après les constatations chromatographiques sur papier la réduction de la chaîne fermée $\mathrm{A}$ et le clivage de la chaîne latérale avaient aussi eu lieu. D'un intérêt particulier était l'observation que les tissus rhumatoïdes avaient converti plus de cortisol en cortisone et moins de cortisone en cortisol. Cela pourrait vouloir dire que la concentration efficace du cortisol était au-dessous de la normale dans la synovie des genoux rhumatoïdes.
Catabolismo e interconversión de cortisol y cortisona en tejido sinovial humano in vitro

\section{SUMARIO}

Se ha demostrado el catabolismo e interconversión de cortisol y cortisona radiactivos en tejido sinovial in vitro. Se obtuvieron muestras de tres articulaciones de rodillas reumatoides y de articulaciones de rodillas de dos sujetos con diabetes debidamente controlada, quienes estaban siendo sometidos a amputaciones de GrittiStokes por gangrena de los dedos de los pies. Cortisol, cortisona, dihidrocortisol 20a-, dihidrocortisol $20 \beta-$, dihidrocortisona $20 a-$, y dihidrocortisona $20 B$ - fueron identificados por recristalización, con normas relacionadas a actividades específicas constantes. Las pruebas con papel cromatográfico revelaron reducción del circulo A y desdoblamiento de la cadena lateral. De particular interés fue el descubrimiento de que los tejidos reumatoides convierten más cortisol en cortisona y menos cortisona en cortisol. Esto podría significar que la concentración efectiva de cortisol era subnormal en la sinovia de las rodillas reumatoides. 